\title{
GLU298ASP and 4G/5G Polymorphisms and the Risk of Ischemic Stroke in Young Individuals
}

\author{
Juan Carlos Esparza-García, David Santiago-Germán, María Guadalupe \\ Valades-Mejía, Jesus Hernández-Juárez, Eberth Aguilar-Sosa, Alfredo Leaños- \\ Miranda, Antonio Alvarado-Moreno, Abraham Majluf-Cruz, Irma Isordia-Salas
}

\begin{abstract}
Background: Polymorphisms in the endothelial nitric oxide synthase (eNOS) and in the plasminogen activator inhibitor -1 (PAI-1) genes have been implicated in stroke pathogenesis but results are still controversial. The aim of this study was to examine the possible contribution of Glu298Asp in the eNOS and 4G/5G in the PAI-1polymorphisms with ischemic stroke in a young Mexican population. Materials and Methods: In a case-control study, conducted between January 2006 and June 2010,204 patients $\leq 45$ years of age with ischemic stroke and 204 controls matched by age and gender, were recruited. The Glu298Asp and 4G/5G polymorphisms were determined in all participants by polymerase chain reaction-restriction fragment length polymorphism. Results: There was a significant difference in the Glu298Asp genotype distribution $(P=0.001)$ and allele frequency between the two groups $(P=0.001)$. The $4 \mathrm{G} / 5 \mathrm{G}$ genotype distribution $(P=0.40)$ and the allele frequency was similar between groups; $(P=0.13)$. There were independent factors for ischemic stroke: Asp carriage (GluAsp + AspAsp) $(\mathrm{P}=0.02)$; smoking $(\mathrm{P}=0.01)$; hypertension $(\mathrm{P}=0.03)$, and familial history of atherothrombotic disease $(\mathrm{P}=0.04)$. Conclusions: The Asp allele from the Gu298Asp gene represents an independent risk factor for ischemic stroke in a young Mexican population. In contrast, the $4 \mathrm{G} / 5 \mathrm{G}$ was not associated with an increased risk for this disease in the same group of patients, as previously has been demonstrated in other populations.
\end{abstract}

RÉSUMÉ: Les polymorphismes Glu298Asp et 4G/5G et le risque d'accident vasculaire cérébral ischémique chez des individus jeunes. Contexte: Des polymorphismes du gène de la synthase de l'oxyde nitrique endothélial (eNOS) et du gène de l'inhibiteur-1 de l'activateur du plasminogène (PAI-1) ont été impliqués dans la pathogenèse de l'accident vasculaire cérébral (AVC), mais les résultats de ces études demeurent controversés. Le but de cette étude était d'examiner la contribution possible du polymorphisme Glu298Asp du gène de l'eNOS et du polymorphisme 4G/5G du gène de PAI-1 à l'AVC dans une population mexicaine jeune. Méthode: Deux cent quatre patients atteints d'un AVC ischémique et 204 témoins appariés pour l'âge et le sexe ont été inclus dans une étude cas-témoin effectuée entre janvier 2006 et juin 2010. Les polymorphismes Glu298Asp et 4G/5G ont été identifiés chez tous les participants au moyen de la technique de réaction en chaîne par polymérase - polymorphismes de longueur des fragments amplifiés. Résultats: Nous avons noté une différence significative dans la distribution du génotype Glu298Asp ( $\mathrm{p}=0,001)$ et la fréquence allélique entre les deux groupes ( $\mathrm{p}=0,001)$. La distribution du génotype $4 \mathrm{G} / 5 \mathrm{G}(\mathrm{p}=0,40)$ et la fréquence allélique étaient similaires dans les deux groupes $(\mathrm{p}=0,13)$. Nous avons noté des facteurs indépendants de l'AVC ischémique : être porteur de GluAsp + AspAsp $(p=0,02)$, être fumeur $(p=0,01)$, hypertendu $(p=0,03)$ et avoir une histoire familiale de maladie athérothrombotique $(\mathrm{p}=0,04)$. Conclusions: L'allèle Asp du gène Glu298Asp est un facteur de risque indépendant de l'AVC ischémique dans une population mexicaine jeune. Par contre, le polymorphisme $4 \mathrm{G} / 5 \mathrm{G}$ n'est pas associé à un risque accru de cette pathologie dans ce groupe de patients, contrairement à ce qui a été démontré dans d'autres populations.

Keywords: Endothelial dysfunction, eNOS, genetic risk, ischemic stroke, plasminogen activator inhibitor

doi:10.1017/cjn.2015.45

Can J Neurol Sci. 2015; 42: 310-316

Stroke has emerged as the second commonest cause of mortality worldwide. ${ }^{1}$ In Mexico, ischemic stroke represents the fourth cause of death and is an important health care issue. ${ }^{2}$ Moreover, ischemic stroke in young adults aged between 15 and 45 years old has a prevalence ranging from 3 to $5 \% .^{3,4}$ In arterial thrombosis at young age, traditional risk factors such as gender, smoking, hypertension, diabetes mellitus, obesity and hypercholesterolemia do not fully explain the thrombotic risk. Therefore,
From the Unidad de Investigación Médica en Trombosis, Hemostasia y Aterogénesis (JCEG, DS, MGV, JH, EA, AA, AM, IS), Servicio de Urgencias (DS) del Hospital "Carlos Mac Gregor Sánchez Navarro"; Unidad de Investigación Médica en Medicina Reproductiva (LA), UMAE HGO 4. Instituto Mexicano del Seguro Social, México, DF, México. Received May 13, 2014. Final Revisions Submitted February 26, 2015. Correspondence to Irma Isordia-Salas, Apartado Postal 12-1100, Mexico 12, México, DF, México. E-mail: irmaisordia@yahoo.com.mx 
additional factors must be present that contribute to the likelihood of developing arterial thrombosis, such as genetic factors. ${ }^{5}$

Previous studies have demonstrated that an impaired fibrinolytic system plays a major role in the pathogenesis of ischemic stroke. ${ }^{6,7}$ Plasmin is the major enzyme in the fibrinolytic system and lyses fibrin clots. The conversion of plasminogen to plasmin is catalyzed by tissue plasminogen activator (tPA) and is inhibited by plasminogen activator inhibitor (PAI-1). Therefore, a high plasma level of PAI-1 is associated with reduced fibrinolytic activity and increased risk for thrombotic events. ${ }^{8}$ The promoter region of the PAI-1 gene contains a common single guanine nucleotide insertion/deletion polymorphism (4G/5G) situated 675 (base pairs) bp from the transcription start site ${ }^{9}$ and it is associated with increased PAI-1 plasma levels. Several studies have demonstrated that PAI-1 levels represent a risk factor for ischemic stroke in some ethnic groups but the PAI-1 concentration was not influence by the $4 \mathrm{G} / 5 \mathrm{G}$ polymorphism. ${ }^{10}$ It has been demonstrated that $4 \mathrm{G} / 5 \mathrm{G}$ polymorphism is significantly associated with an increased risk of stroke, ${ }^{11}$ but other studies failed to confirm this association. ${ }^{12-15}$ It has been described that this polymorphism represents a protector effect for ischemic stroke in young and older individuals, ${ }^{16}$ but results are still controversial.

One of the most important products of endothelial cells is nitric oxide (NO), a major mediator of endothelium dependent vasodilation made in the endothelial cells from l-arginine through the action of the homodimeric enzyme endothelial nitric oxide synthase (eNOS). Nitric oxide has critical roles in the regulation of vascular homeostasis and prevention of atherogenesis by inhibiting leukocyte, platelet activation and smooth muscle cell proliferation. ${ }^{17}$ There is a guanine to thymine (Glu298Asp) polymorphism at position 894 of the eNOS gene and the T allele (298Asp) had been described associated with an increased risk for coronary artery disease (CAD) ${ }^{18}$ and hypertension, ${ }^{19}$ however, those findings have not been corroborated by others. ${ }^{20}$ Moreover, the Glu298Asp polymorphism has been identified as an independent risk factor for carotid atherosclerosis and ischemic stroke. ${ }^{21-25}$

Those polymorphisms have not been analyzed in our Mexican population. Therefore, the aim of this study was to evaluate the effect of the Glu298Asp and 4G/5G polymorphisms on the risk for ischemic stroke in patients $\leq 45$ years of age.

\section{MATERIALS AND METHODS}

\section{Study group}

A total of 204 consecutive, unrelated patients $\leq 45$ years old, with diagnosis of ischemic stroke were enrolled between January 2006 and June 2010. Diagnosis of ischemic stroke was considered in all patients after an acute focal neurological deficit with duration greater than 24 hours, confirmed by means of brain computed tomography or magnetic resonance imagery. Also, cardiac/transcardiac and carotid or vertebral artery sources of emboli as well as cervical arterial dissection were always excluded by means of transesophageal and transthoracic echocardiogram, cardiac magnetic resonance, magnetic resonance angiography and carotid and vertebral Doppler ultrasound. Patients with cerebral hemorrhage were not included in the study. We performed chromogenic assays to evaluate functional levels of antithrombin, protein $\mathrm{C}$ and protein $\mathrm{S}$ (Diagnostica Stago). We also determined lupus anticoagulant (DVV test, DVV confirm®; American Diagnostic, USA), modified activated protein $\mathrm{C}$ resistance (normal ratio >2.0, Coatest + APC Resistance V-S; Chromogenix, Sweden) and anticardiolipin antibodies (normal value $<10 \mathrm{U}$; Sanofi Diagnostics Pasteur, France). Lupus anticoagulant and anticardiolipin antibodies tests were performed. The control group was constituted by 204 individuals without history of cerebrovascular disease. Age, sex, use of oral contraceptives and history of thrombotic events or drug abuse were recorded.

Other risk factors for atherothrombotic disease were noted. Patients of 45 years old or younger were included to minimize the effect of long-term environmental influences on disease etiology. Hypertension was defined if a subject fulfilled the European Society Cardiology criteria, or they were already being treated with antihypertensive drugs. A family history of CAD was defined as $\mathrm{CAD}$ or sudden death in a first-degree male relative younger than 55 years of age or a female relative younger than 65 years of age. Patients were considered smokers if they were currently smoking or had ceased within the last 12 months. Subjects were considered to be dyslipidemia if they had a cholesterol level of $200 \mathrm{mg} / \mathrm{dl}$, or if they were being already treated. Individuals were considered with diabetes if they has fasting glycemia $>126 \mathrm{mg} / \mathrm{dl}$, or if they were already diagnosed as diabetic. The $4 \mathrm{G} / 5 \mathrm{G}$ polymorphism in the PAI-1 gene, and the Glu298Asp in the eNOS gene, were determined in all participants.

\section{Ethics}

The study protocol was reviewed and approved by the Human Ethical Committee, and Medical Research Council of the Instituto Mexicano Del Seguro Social and conforms to the ethical guidelines of the 1975 Declaration of Helsinki. Informed written consent was obtained from all subjects before enrollment.

\section{DNA extraction and Genotyping}

Genomic DNA was extracted from whole blood samples using standard methods (QIAamp DNA Blood Mini Kit, Qiagen GmbH, Hilden Germany). For detection of the 1Glu298Asp polymorphism on the eNOS, we used primer pairs to amplify a part of the eNOS gene containing exon 7 , by polymerase chain reaction (PCR) with the following flanking intronic primers: (sense) 5'CATGAGGCTCAGCCCCAGAAC-3' and (antisense) 5' AGT CAA TCC CTT TGC RGC TCAC-3', followed by Mbo I

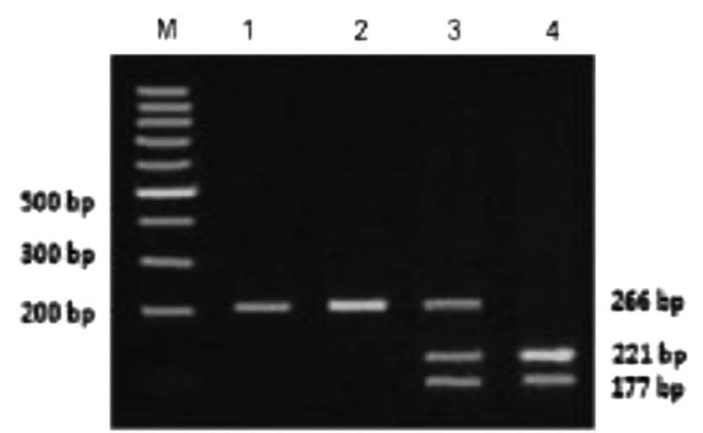

Figure 1: Genotypic determination of the polymorphism Glu298Asp of the eNOS gene. Agarose gel electrophoresis of PCR products after endonuclease restriction with enzyme Mbol. Lane 1 represents undigested PCR amplification of 266 bp fragments. Line 2, Glu/Glu homozygote, line 3 Glu/Asp heterozygote, and lane 4, Asp/Asp homozygote. M represents $100 \mathrm{bp}$ ladder. DNA fragment sizes, in base pairs, are indicated by numbers on the right. 


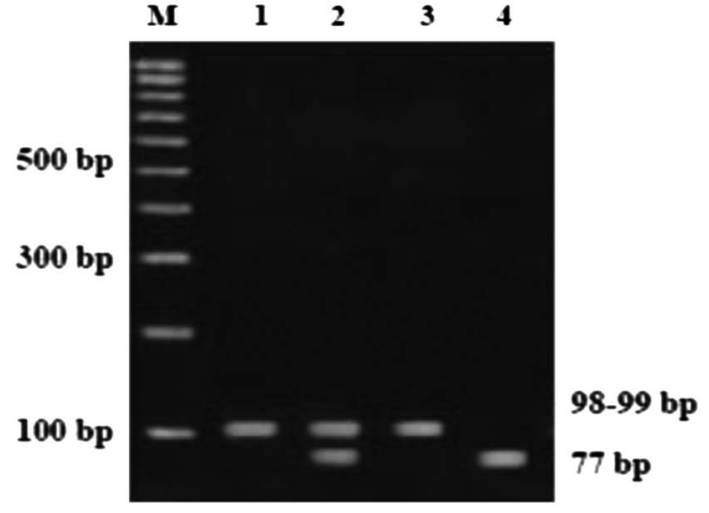

Figure 2: Agarose electrophoretic gel analysis of the $4 G / 5 G$ polymorphic region of PAI-1. M represents $100 \mathrm{bp}$ molecular weight marker; lines 1 represents the 99-98 bp polymorphic fragment, line 2 the fragment corresponding to the genotype $4 G / 5 G$ (98-77bp) after digestion with BsI I (98bp), line 3 represents the genotype 4G/5G after digestion with BsI I (98bp), line 4 the fragment corresponding the genotype $5 G / 5 G(77 \mathrm{bp})$.

(New England Biolabs, Beverly Mass) restriction endonuclease digestion for eight hours at $37^{\circ} \mathrm{C}$ and resolution by electrophoresis on 3\% agarose gel (BIO-RAD Laboratories Hercules, CA). WI). Amplifications were performed in a Thermo Cycler (Applied Byosistem, Foster CA). Polymerase chain reaction was performed by denaturation at $94^{\circ} \mathrm{C}$ for 30 seconds (sec), annealing segment at $60^{\circ} \mathrm{C}$ for $30 \mathrm{sec}$, and extension at $72^{\circ} \mathrm{C}$ for $30 \mathrm{sec}$, repeated for 30 cycles. The resulting 206 base pair (bp) polymerase chain reaction product was cleaved into two smaller fragments of 119 and $87 \mathrm{bp}$ in the presence of a T nucleotide at 894 (corresponding to Asp 298) but not in its absence (wild type). Digestion fragments were resolved by electrophoresis on $2.5 \%$ agarose gel stained with ethidium bromide (Figure 1).

Genotyping of $4 \mathrm{G} / 5 \mathrm{G}$ polymorphism in the PAI-1 promoter region was performed by PCR using the following oligonucleotides: 5'CACAGAGAGAGTCTGGCCACGT-3'(sense) and 5'CCAACAGAGGACTCTTGGTCT-3' (antisense). The reaction conditions were as follow: initial denaturation at $94^{\circ} \mathrm{C}$ for three

Table 1: Demographic and clinical characteristics of patients with ischemic stroke and controls

\begin{tabular}{l|c|c|c}
\hline & Patients & Controls & p value* \\
\hline & $(\mathbf{n = 2 0 4 )}$ & $(\mathbf{n = 2 0 4})$ & \\
\hline Age, years (mean \pm SD) & $34.1 \pm 5.4$ & $33.5 \pm 6.1$ & NS \\
\hline Female n (\%) & $119(58.3)$ & $120(58.8)$ & \\
\hline Diabetes Mellitus n (\%) & $18(8.8)$ & $11(5.4)$ & 0.18 \\
\hline Hypertension n (\%) & $27(13.2)$ & $14(6.7)$ & 0.03 \\
\hline Current smoking n (\%) & $52(25.5)$ & $33(16.9)$ & 0.02 \\
\hline Dyslipidemia n (\%) & $87(42.6)$ & $91(44.6)$ & 0.70 \\
\hline Family history of ATD & $49(24.0)$ & $26(13.7)$ & 0.02 \\
\hline
\end{tabular}

*t test for continuous variables; chi square or Fisher exact test for proportions

ATD $=$ Atherothrombotic disease NS $=$ Not significant minutes (min) followed by 30 cycles of denaturation at $94^{\circ} \mathrm{C}$ for three sec, alignment at $60^{\circ} \mathrm{C}$ for $30 \mathrm{sec}$, and an extension step at $72^{\circ}$ $\mathrm{C}$ for $30 \mathrm{sec}$, followed by a final linear extention at $72^{\circ} \mathrm{C}$ for one min. Products were subjected to digestion with restriction enzyme BsI I (New England Biolabs, Beverly, Massachussetts, USA) at 55 C. The DNA fragments were separated by electrophoresis in 3\% agarose gel (BIO-RAD Laboratories, Hercules, California, USA) and visualized using ethidium bromide. All samples were processed in duplicated. Some were subject to sequencing (Figure 2).

\section{Statistical analysis}

Continuous data are expressed as the mean \pm standard deviation (SD); categorical data are expressed with percentages. The significance of differences between continuous variables was determined by Student's $t$ test. Differences between categorical variables, was determined with the chi square test. Adjusted odds ratio (OR) was calculated by multivariate logistic regression analyses for $4 \mathrm{G} / 5 \mathrm{G}$ and Glu298Asp polymorphism and traditional cardiovascular risk factors. A $P$ value $<0.05$ was considered as statistically significant. All statistical analyses were performed using SPSS (Statistical Package for the Social Sciences) statistical software package (version 15: SPSS Inc, Chicago, IL, USA).

\section{RESULTS}

Baseline characteristics of patients and controls are shown in Table 1. Ethnic background of all patients and controls was Mexican. All patients were 45 years of age or less at the time of the ischemic stroke. The original sample was conformed by 251 patients. However, we found 33 patients with thrombophilic conditions and those patients were excluded from this study. Fourteen patients were diagnosed with cerebral hemorrhage and also were excluded. In the final sample of 204 patients, we found evidence of 153 patients with cryptogenic stroke and 51 patients with smallvessel disease. Mean age for the group of patients was $34.1 \pm 5.4$ while mean age for the control group was $33.5 \pm 6.1$ years. There was no difference in terms of gender between both groups $(\mathrm{P}=0.5)$, or diabetes mellitus between the groups $(P=0.18)$, patients with stroke had a higher prevalence of conventional risk factor for atherothrombotic disease. We performed thrombophilia screening only in the patients. We found protein S deficiency (7), protein C deficiency (1), anticardiolipin antibodies (15), lupus anticoagulant (6), acquired activated protein $\mathrm{C}$ resistance (4) and antithrombin deficiency (1). One patient had two thrombophilic conditions. All 33 patients were excluded from this study.

Hypertension was higher in the group of patients (13.2\% vs. $6.7 \%, \mathrm{OR}=2.07 ; 95 \% \mathrm{CI}=1.01-4.31, \mathrm{P}=0.03)$, as was smoking frequency $(25.5 \%$ vs. $16.9 \%$, OR $=1.77 ; 95 \% \mathrm{CI}=1.06-2.97$, $\mathrm{P}=0.02)$. There was no significant difference between the groups in terms of dyslipidemia $(\mathrm{P}=0.7)$.

Table 2 shows the genotype distribution and allele frequency of Glu298Asp polymorphism among patients and controls and directly compares each genotype and allele among both groups. There was a significant difference in the genotype distribution between both groups $(\mathrm{P}=0.001)$. The genotype distribution in the control group was 146 individuals $(71.6 \%)$ homozygous for the allele Glu, 52 (25.5\%) heterozygous Glu/Asp, and $6(2.9 \%)$ homozygous for the allele Asp. There was significant difference in the allele frequency $(\mathrm{P}=0.001)$. For patients and controls, frequencies of the Glu allele were $73.5 \%$ and $84.35 \%$, 
Table 2: Genotype distribution and allele frequency of Glu298Asp and 4G/5G polymorphisms among patients with ischemic stroke and controls

\begin{tabular}{|c|c|c|c|c|c|c|c|}
\hline Genotype & Patients & Controls & P value ${ }^{a}$ & Genotype & Patients & Controls & P value* \\
\hline & $n=204$ & $n=204$ & & & $n=204$ & $n=204$ & \\
\hline Glu/Glu & $107(52.4 \%)$ & $146(71.6 \%)$ & $0.001 *$ & $4 \mathrm{G} / 4 \mathrm{G}$ & $23(11.3 \%)$ & $16(7.8 \%)$ & $0.40 *$ \\
\hline Glu/Asp & $86(42.2 \%)$ & $52(25.5 \%)$ & & $4 \mathrm{G} / 5 \mathrm{G}$ & $94(46.1 \%)$ & $87(42.6 \%)$ & \\
\hline Asp/asp & $11(5.4 \%)$ & $6(2.9 \%)$ & & $5 \mathrm{G} / 5 \mathrm{G}$ & $87(42.6 \%)$ & $101(49.6 \%)$ & \\
\hline Glu/Glu vs & $107(52.4)$ & $146(71.6 \%)$ & $0.001 *$ & $4 \mathrm{G} / 4 \mathrm{G}+4 \mathrm{G} / 5 \mathrm{G}$ & $117(57.4 \%)$ & $103(50.4 \%)$ & $0.14 *$ \\
\hline Glu/Asp + Asp/Asp & $97(47.6 \%)$ & $58(28.4 \%)$ & & vs. $5 \mathrm{G} / 5 \mathrm{G}$ & $87(42.6 \%)$ & $101(49.6 \%)$ & \\
\hline Allele & & & & Allele & & & \\
\hline Glu & $300(73.5 \%)$ & $344(84.35 \%)$ & $0.001 *$ & $4 \mathrm{G}$ & $140(34.35 \%)$ & $119(29.0 \%)$ & $0.13 *$ \\
\hline Asp & $108(26.5 \%)$ & $64(15.65 \%)$ & & $5 \mathrm{G}$ & $268(65.65 \%)$ & $101(71.0 \%)$ & \\
\hline
\end{tabular}

Data presented are number $(\%)$ of patients. $*=\chi^{2}$ test

respectively. The univariate analysis identified the Asp allele as a risk factor for ischemic stroke (homozygous Asp/Asp and heterozygous Glu/Asp carriers), as compared with homozygous for Glu/Glu allele $(\mathrm{OR}=2.28,95 \% \mathrm{CI}=1.48-3.51, \mathrm{P}=0.01)$.

Table 2 shows the genotype distribution and allele frequency of $4 \mathrm{G} / 5 \mathrm{G}$ polymorphism among patients and controls and compares genotype and alleles among both groups.. There was a significant difference in the genotype distribution between both groups $(\mathrm{p}=0.001)$. The genotype distribution in the control group was 16 individuals $(7.8 \%)$ homozygous for the allele $4 \mathrm{G}, 87$ (42.6\%) heterozygous 4G/4G, and 101 (49.6\%) homozygous for the allele $5 \mathrm{G}$. There was no significant difference in the allele frequency $(\mathrm{P}=0.13)$. For patients and controls, frequencies of the $4 \mathrm{G}$ allele were $34.35 \%$ and $29.0 \%$, respectively.

Table 3; According to the adjusted ORs, four independent risk factors were associated with stroke: Asp carriage (GluAsp + AspAsp) $(\mathrm{OR}=1.75,95 \% \mathrm{CI} 95=1.0-2.14, \mathrm{P}=0.02)$; smoking $(\mathrm{OR}=2.42, \quad 95 \% \quad \mathrm{CI}=1.0-3.40, \quad \mathrm{P}=0.01) ; \quad$ hypertension $(\mathrm{OR}=2.54,95 \mathrm{CI} \%=1.08-4.32, \mathrm{P}=0.03)$, and familial history of atherothrombotic disease $(\mathrm{OR}=1.79,95 \mathrm{CI} \% 1.02-2.57, \mathrm{P}=0.04)$.

\section{DISCUSSION}

Ischemic stroke is the third leading cause of death worldwide and the most common cause of disability in the adult population. ${ }^{1}$ Previous reports described the Glu298Asp and 4G/5G polymorphisms as risk factors for coronary and cerebral ischemic

Table 3: Multiple logistic regression analysis using ischemic stroke as the dependent variable

\begin{tabular}{l|c|c|c}
\hline Risk Factor & OR & $\mathbf{9 5 \%}$ CI & P value* \\
\hline Hypertension & 2.54 & $1.08-4.32$ & 0.03 \\
\hline Asp allele & 1.75 & $1.0-2.14$ & 0.02 \\
\hline Smoking & 2.42 & $1.0-3.40$ & 0.01 \\
\hline Familial history of ATD & 1.79 & $1.02-2.27$ & 0.04 \\
\hline Diabetes & 1.04 & $0.89-2.30$ & 0.40 \\
\hline
\end{tabular}

* chi square test multivariate logistic-regression; OR: adjusted odds ratio; $\mathrm{ATD}=$ Atherothrombotic disease disease. ${ }^{20,22-25}$ However, only a few studies were done in young patients and the results are controversial. ${ }^{26}$ Clinical and epidemiological studies have demonstrated an association between this polymorphism and the eNOS activity or endothelial function. In agreement with previous studies, we identified the Asp allele as an independent risk factor for ischemic stroke. ${ }^{22,23}$ However, more important is the fact that this association persisted after adjustment for other classical risk factors for cerebral ischemic disease. Previously reports by Elbaz et al demonstrated, in a French population, that the Glu298Asp genotype was associated with brain infarction especially with lacunar stroke. ${ }^{22}$ Further subgroup analysis demonstrated an association between lacunar strokes and low density lipoprotein (LDL) cholesterol level, with a possible synergistic action of lacunar stroke. The Glu allele frequency reported by Elbaz et al, was little lower compared with the frequency found in the present study: $60.7 \%$ vs $73.6 \%$, respectively. The positive association between the polymorphism and ischemic stroke was corroborated by Cheng and co workers in Chinese population. ${ }^{27}$ In a recent study, Szolnoki et al, demonstrated that the eNOS Glu298Asp or eNOS Asp298Asp genotypes combination with MTHFR 677TT or ACE DD increased the risk of ischemic stroke in a Caucasian population. ${ }^{23}$ Several studies have demonstrated that the genetic variation Glu298Asp represents an independent risk factor for increased susceptibility to ischemic stroke. ${ }^{24,28}$ In contrast, Markus and co worker showed no association between Glu298Asp and stroke or transient ischemic attack secondary to large vessel atherosclerosis, or with the degree of carotid stenosis in patients with cerebrovascular disease. $^{21}$

Several experimental studies have demonstrated that NO inhibits many key steps of atherosclerotic disease and a defect in NO production could facilitate the progression of the atherosclerotic process. In fact, NO, besides its potent vasorelaxant effect, plays an important role in the regulation of blood pressure and regional blood flow. Also, NO is involved in the inhibition of platelet adhesion and aggregation, leukocyte adhesion and of smooth muscle cell migration and proliferation. ${ }^{29,30}$ The deficiency of NO is considered an important risk factor for endothelial dysfunction, which is an important contributor to ischemic stroke. Increased levels of homocysteine has been related to endothelial dysfunction. Recent studies demonstrated an association between the C677T polymorphism and hyperhomocysteinemia, with an 
increased risk for vascular occlusive disease. Earlier studies identified a common polymorphism (C677T) in the gene encoding the MTHFR as a genetic risk factor for stroke. ${ }^{31}$ The results from the VITATOPS $^{32}$ were that daily administration of folic acid, vitamin B6, and vitamin B12 to patients with recent stroke or transient ischaemic attack was safe but did not seem to be more effective than placebo in reducing the incidence of major vascular events.

We have previously shown that the $\mathrm{T}$ allele of the MTHFR C677T is a risk factor for ischemic stroke in the same subgroup of Mexican subjects. ${ }^{33}$ Arterial thrombus formation is believed to be an essential event in the pathogenesis of stroke. Therefore, it has been proposed that decreasing the fibrinolytic system plays on important role in this process.

In the present study, there was no association between the $4 \mathrm{G}$ allele and ischemic stroke in the same group of patients. Our results are similar to those described by de Sabino et al, in a Brazilian population with a negative association between the $4 \mathrm{G}$ allele and ischemic stroke ${ }^{34}$. Also, similar results were reported by Jood et al, in 600 patients with acute ischemic stroke aged 18 to 69 years and 600 matched community controls. ${ }^{14}$ Earlier results from Hoekstra et al, provided support for a protective effect of the $4 \mathrm{G}$ allele against stroke, which is notable given the direct relationship between stroke and PAI-1 activity. ${ }^{35}$ Jeppesen et al, demonstrated that $4 \mathrm{G} / 5 \mathrm{G}$ polymorphism is associated with plasma levels but not with stroke risk in the elderly. ${ }^{36}$ This finding is also consistent with two prospective studies showing reduced risk of stroke and cerebrovascular mortality for the 4G4G genotype in the elderly. ${ }^{16}$

The explanation of the reduced risk of stroke for PAI-1 4G/5G polymorphism remains speculative but may be found in a vascular pathological pathway that does not involve fibrinolysis. ${ }^{16}$ It has been demonstrated that PAI-1 serves a protective role, involving suppression of matrix-degrading enzymes in the plaque, resulting in limited plaque growth and prevention of abnormal matrix remodeling. ${ }^{37}$ Therefore, a local increase of tissue PAI-1 associated with the $4 \mathrm{G}$ allele may stabilize plaques, thereby reducing the risk of cerebrovascular disease. Another possible explanation may be that PAI-1 inhibits neurotoxicity of tissue plasminogen activation in the brain. ${ }^{16,38}$

Our results are similar to those described for Babu et al, ${ }^{39}$ in a Tunisian population. They found no association between the $4 \mathrm{G} / 5 \mathrm{G}$ polymorphism and stroke. Moreover, Saidi et al, ${ }^{40}$ found a protective effect of $4 \mathrm{G}$ allele in an older population. They postulated a similar mechanism not related to fibrinolysis, possibly involving altered plaque stabilization, and /or through antagonism of tPA effects.

In a previous study by Fernandez et al, it was demonstrated in 165 patients, with ischemic stroke who received t-PA within three hours, that PAI-1 4G/5G patients had higher reoclussion rates compared with other genotypes ( $12.5 \%$ vs. $2.7 \%$ ). Also, the $4 \mathrm{G} /$ $4 \mathrm{G}$ genotype was associated with poor functional outcome at the third month compared with the other genotypes. ${ }^{41}$ However, that finding has to be confirmed with bigger samples in future studies.

Moreover, we had previously reported that the $4 \mathrm{G} / 5 \mathrm{G}$ polymorphism is associated with an increased risk factor for ST segment elevation myocardial infarction in young Mexican individuals. $^{42}$ Those results probably suggest that the $4 / 5 \mathrm{G}$ polymorphism may not have the same influence on ischemic stroke or is involved in different pathophysiological mechanisms in each of those territories. $^{43}$

Several studies had demonstrated that thrombosis disease is influenced by a complex interplay of procoagulant, anticoagulant, fibrinolytic, endothelial damage/dysfunction and inflammatory processes. Therefore, the present results suggest that in young patients with ischemic stroke, those polymorphisms may contribute to the premature endothelial dysfunction and thrombus formation.

In the present study, hypertension and smoking represented independent risk factors for stroke after adjustment for other variables. ${ }^{44}$ Diabetes mellitus and dyslipidemia were not associated with ischemic stroke in this group of patients and these results are similar to previously described by others investigators. In contrast, studies in older populations with ischemic stroke found that diabetes mellitus and dyslipidemia were associated with this disease. ${ }^{45}$ Based on these facts, we consider that thrombotic risk factors may not have the same influence on ischemic stroke in young patients as compared with older individuals and that the interaction between them and specific genetic variants may be different for each group of age. ${ }^{46}$ Therefore, a specific genotype-environmental combination may determine several possible phenotypes at different moments in life. Moreover, the specific influence of each known genetic abnormality associated with ischemic stroke may not be the same for every race. Therefore, it is desirable to establish the specific contribution of each genetic or environmental risk factor in individuals with different genetic backgrounds. ${ }^{47}$ The knowledge of new genetic risk markers will permit recognition of a larger population at high risk of ischemic stroke, and this may lead to more effective prevention. ${ }^{48}$

Our study has several limitations, such as the small sample size, the lack of NO and PAI-1 level measurements and its correlation to genetic data. Meanwhile, the present study also has several strengths: 1) All ischemic stroke patients and controls has a similar ethnic background, and were matched by age and gender. 2) In the study patients of 45 years old or younger were included to minimize the effect of long-term environmental influences on disease etiology. 3) Laboratory genotyping was performed in a blinding manner, minimizing measurement bias.

In conclusion, our results demonstrated that the Asp allele from the Glu298Asp polymorphism represents an independent risk factor for ischemic stroke in young Mexican population. Moreover, hypertension, smoking and family history of thrombosis disease represented individual risk factors for ischemic stroke in our population. In contrast, the $4 \mathrm{G}$ allele was not associated with an increased risk for this disease in the same group of patients, as previously has been demonstrated in other populations.

\section{ACKNOWLEDGMents}

This research was supported by El Fondo de Investigación en Salud IMSS grants (FIS/IMSS/PROT/G09/748); (FIS/IMSS/ PROT/PRIO/13/023), CONACyT Consolidación de Grupos de Investigación modalidad repatriación (No. 050232) and Apoyo Complementario para Investigadores Nivel 1 No. (118254) and a Grant from Fundación IMSS, AC. (to I.I.S.).

\section{Disclosures}

None of the authors have anything to disclose.

JCEG and DS contributed equally to this study.

\section{CONFLICTS OF INTEREST}

None declared. 


\section{REFERENCES}

1. American Heart Association. Heart disease and stroke statistics 2009 update: a report from the American Heart Association Statistics Committee and Stroke statistics Subcommittee. Circulation. 2009;119:e21-181.

2. Instituto Nacional de Estadística, Geografía e Informática. Censo Nacional de Población y Vivienda 2008 (México). Available at: http://www.inegi.org.mx.

3. Ferro JM1, Massaro AR, Mas JL. Aetiological diagnosis of ischaemic stroke in young adults. Lancet Neurol. 2010;9:1085-96.

4. Putaala J, Metso AJ, Metso TM, et al. Analysis of 1008 consecutive patients aged from 15 to 49 with first event ischemic stroke: the Helsinki young stroke registry. Stroke. 2009;40:1195-203.

5. Pruissen DM, Kappelle LJ, Rosendaal FR, Algra A. Genetic association studies in ischaemic stroke: replication failure and prospects. Cerebrovasc Dis. 2009;27:290-4.

6. Kristensen B1, Malm J, Nilsson TK, Hultdin J, Carlberg B, Olsson T. Increased fibrinogen levels and acquired hypofibrinolysis in young adults with ischemic stroke. Stroke. 1998;29:2261-7.

7. Kain K, Young J, Bamford J, Bavington J, Grant PJ, Catto AJ. Determinants of plasminogen activator inhibitor-1 in South Asians with ischaemic stroke. Cerebrovasc Dis. 2002;14:77-83.

8. Dawson S, Henney A. The status of PAI-1 as a risk factor for arterial and thrombotic disease: a review. Atherosclerosis. 1992:95:105-17.

9. Dawson SJ, Wiman B, Hamsten A, Green F, Humphries S, Henney AM. The two allele sequences of a common polymorphism in the promoter of the plasminogen activator inhibitor-1 (PAI-1) gene respond differently to interleukin-1 in HepG2 cells. J Biol Chem. 1993;268:10739-45

10. Xu X, Li J, Sheng W, Liu L. Meta-analysis of genetic studies from journals published in China of ischemic stroke in the Han Chinese population. Cerebrovasc Dis. 2008;26:48-62.

11. Bang Co, Park HK, Ahn MY, Shin HK, Hong SY. 4G/5G polymorphism of the plasminogen activator inhibitor- 1 gene and insertion/deletion polymorphism of the tissue-type plasminogen activator gene in atherothrombotic stroke. Cerebrovasc Dis. 2001;11:294-9.

12. Ding J, Nicklas BJ, Fallin MD, de Rekeneire N, Kritchevsky SB, Pahor M, Rodondi N, Li R, Zmuda JM, Harris TB. Plasminogen activator inhibitor type 1 gene polymorphisms and haplotypes are associated with plasma plasminogen activator inhibitor type 1 levels but not with myocardial infarction or stroke. Am Heart. 2006;152:1109-15.

13. van Goor ML, Gómez García E, Leebeek F, Brouwers GJ, Koudstaal P, Dippel D. The plasminogen activator inhibitor (PAI-1) 4G/5G promoter polymorphism and PAI-1 levels in ischemic stroke. A case-control study. Thromb Haemost. 2005;93:92-6.

14. Jood K, Ladenvall $\mathrm{P}$, Tjärnlund-Wolf $\mathrm{A}$, et al. Fibrinolytic gene polymorphism and ischemic stroke. Stroke. 2005;36:2077-81.

15. Catto AJ, Carter AM, Bamford JM, Davis JA, Grant PJ. Plasminogen activator inhibitor-1 (PAI-1) 4G/5G promoter polymorphism and levels in subjects with cerebrovascular disease. Thromb Haemost. 1997;77:730-4.

16. Roest M, van der Schouw YT, Banga JD, et al. Plasminogen activator inhibitor $4 \mathrm{G}$ polymorphism is associated with decreased risk of cerebrovascular mortality in older women. Circulation. 2000;101:67-70.

17. Lloyd-Jones DM, Bloch KD. The vascular biology of nitric oxide and its role in atherogenesis. Annu Rev Med. 1996;47:365-75.

18. Cam SF, Sekuri C, Tengiz I, et al. The G894T polymorphism on endothelial nitric oxide syntahse gene is associated with premature coronary artery disease in a Turkish population. Throm Res. 2005;116:287-92.

19. Rossi GP, Taddei S, Virdis A, et al. The T786C and Glu298Asp polymorphism of the endothelial nitric oxide gene affect the forearm blood flow blood flow response of Caucasian hypertensive patients. J Am Coll Cardiol. 2003;41:938-45.

20. Lembo G, De Luca N, Battagli C, et al. A common variant of endothelial nitric oxide synthase (Glu298Asp) is an independent risk factor for carotid atherosclerosis. Stroke. 2001;32:735-40.

21. Zalba G, Fortuño A, San José G, Moreno MU, Beloqui O, Díez J. Oxidative stress. Endothelial dysfunction and cerebrovascular disease. Cerebrovasc Dis. 2007;24(Suppl 1):24-9.

22. Elbaz A, Poirier O, Moulin T, Chédru F, Cambien F, Amarenco P. Association between the Glu298Asp polymorphism in the endothelial constitutive nitric oxide synthase gene and brain infarction. The GENIC Investigators. Stroke. 2000;31:1634-9.

23. Szolnoki Z, Havasi V, Bene J, et al. Endothelial nitric oxide synthase gene interactions and the risk of ischaemic stroke. Acta Neurol Scand. 2005;111:29-33.

24. Guldiken B, Sipahi T, Guldiken S, et al. Glu298Asp polymorphism of the endothelial nitric oxide synthase gene in Turkish patients with ischemic stroke. Mol Biol Rep. 2009;36:1539-43.

25. Majumdar V, Nagaraja D, Karthik N, Christopher R. Association of endothelial nitric oxide synthase gene polymorphisms with earlyonset ischemic stroke in South Indians. J Atheroscler Thromb. 2010; $17: 45-53$

26. Isordia-Salas I, Leaños-Miranda A, Borrayo-Sánchez G. The Glu298Asp polymorphism of the endothelial nitric oxide synthase gene is associated with premature ST elevation myocardial infarction in Mexican population. Clin Chim Acta. 2010;411:553-7.

27. Cheng J, Liu J, Li X, et al. Effect of polymorphisms of endothelial nitric oxide synthase on ischemic stroke: a case-control study in a Chinese population. Clin Chim Acta. 2008;392:46-51.

28. Saidi S, Mallat SG, Almawi WY, Mahjoub T. Endothelial nitric oxide synthase Glu298Asp, 4b/a, and $-786 \mathrm{~T}>\mathrm{C}$ gene polymorphisms and the risk of ischemic stroke. Acta Neurol Scand. 2010;121:114-9.

29. Arnal JF, Dinh-Xuan AT, Pueyo M, Darblade B, Rami J. Endothelium-derived nitric oxide and vascular physiology and pathology. Cell Mol Life Sci. 1999;55:1078-87.

30. Radomski M, Palmer RMJ, Moncad S. An L-arginine/nitric oxide pathway present in human platelets regulates aggregation: Proc Natl. Acad. Sci USA. 1990;87:5193-7.

31. Croninn S, Furie KL, Kelly PJ. Dose-related association of MTHFR $677 \mathrm{~T}$ allele with risk of ischemic stroke: evidence from a cumulative meta-analysis. Stroke. 2005;36:1581-7.

32. VITATOPS Trial Study Group. B vitamins in patients with recent transient ischaemic attack or stroke in the VITAmins TO Prevent Stroke (VITATOPS) trial: a randomised, double-blind, parallel, placebo-controlled trial. Lancet Neurol. 2010;9:855-65.

33. Isordia-Salas I, Barinagarrementería-Aldatz F, Leaños-Miranda A, et al. The C677T polymorphism of the methylenetetrahydrofolate reductase gene is associated with idiopathic ischemic stroke in the young Mexican-Mestizo population. Cerebrovasc Dis. 2010;29:454-9.

34. de Paula Sabino A, Ribeiro DD, Domingueti CP, et al. Plasminogen activator inhbitor-1 4G/5G promoter polymorphism and PAI-1 plasma levels in young patients with ischemic stroke. Mol Biol Rep. 2011;38:5355-60.

35. Hoekstra T, Geleijnse JM, Kluft C, Giltay EJ, Kok FJ, Schouten EG. $4 \mathrm{G} / 4 \mathrm{G}$ genotype of PAI-1 gene is associated with reduced risk of stroke in elderly. Stroke. 2003;34:2822-8.

36. Jeppesen LL, Wilhelmsen K, Nielsen LB, et al. An Insertion/Deletion polymorphism in the promoter region of the plasminogen activator inhibitor-1 gene is associated with plasma levels but not with stroke risk in the elderly. J Stroke Cerebrovascular Dis. 1998;385-90.

37. Shah PK, Falk E, Badimon JJ, et al. Human monocyte-derived macrophages induce collagen breakdown in fibrous caps of atherosclerotic plaques. Potential role of matrix-degrading metalloproteinases and implications for plaque rupture. Circulation. 1995;92:1565-9.

38. Chen ZL, Strickland S. Neuronal death in the hippocampus is promoted by plasmin-catalyzed degradation of laminin. Cell. 1997;91:917-25.

39. Babu MS, Prabha TS, Kaul S, et al. Association of genetic variants of fibrinolytic system with stroke and stroke subtypes. Gene. 2012;495:76-80.

40. Saidi S, Slamia LB, Mahjoub T, Ammou Sb, Almawi WY. Association of PAI-1 4G/5G and -844G/A gene polymorphism and changes in the PAI-1/tPA levels in stroke: a case control study. J Stroke Cerebrovasc Dis. 2007;16:153-9.

41. Fernández-Cárdenas I, Del Río-Espínola A, Rubiera M, et al. PAI-1 $4 \mathrm{G} / 5 \mathrm{G}$ polymorphism is associated with brain vessel reoclusion after successful fibrinolytic therapy in ischemic stroke patients. Int J Neurosci. 2010;120(4):245-51.

42. Isordia-Salas I, Leaños-Miranda A, Sainz IM, Reyes-Maldonado E, Borrayo-Sánchez G. Association of the plasminogen activator inhibitor-1 gene 4G/5G polymorphism with ST elevation acute myocardial infarction in young patients. Rev Esp Cardiol. 2009;62:365-72. 
43. Boncoraglio GB, Bodini A, Brambilla C, Carriero MR, Ciusani E, Parati EA. An effect of the PAI-1 4G/5G polymorphism on cholesterol levels may explain conflicting associations with myocardial infarction and stroke. Cerebrovasc Dis. 2006;22:191-5.

44. Madonna P, de Stefano V, Coppola A, et al. Hyperhomocysteinemia and other inherited prothrombotic conditions in young adults with a history of ischemic stroke. Stroke. 2002;33:52-6.

45. Pezzini A, Grassi M, Del Zotto E, et al. Cumulative Effect of predisposing genotypes and their interaction with modifiable factors on the risk of ischemic stroke in young adults. Stroke. 2005;36:533-9.

46. Donnan G.A, You R, Thrift A, McNeil JJ. Smoking as a risk factor for stroke. Cerebrovasc Dis. 1993;3:129-38.

47. Vila N. A genetic approach to ischemic stroke therapy. Cerebrovasc Dis. 2004;17(Suppl 1):63-9.

48. Gállego J, Martínez Vila E, Muñoz R. Patients at high risk for ischemic stroke: identification and actions. Cerebrovasc Dis. 2007;24(Suppl 1):49-63. 